\title{
Evaluation of Insecticidal Efficacy of Piper Guineenseon Fish Beetle (Dermestes maculatus)
}

\author{
Ufele Angela Nwogor, Ogbumuo Prisca Ndidi, Ezeonyejiaku Demian Chigozie, \\ Mogbo Tochukwu Chinedu, Ebenebe Cordelia Ifeyinwa, Aziagba, Bibian Okwuchukwu
}

Zoology Department, Nnamdi Azikiwe University, Awka, Anambra State Nigeria

Email address:

ufeleangel@yahoo.com (U. A. Nwogor)

\section{To cite this article:}

Ufele Angela Nwogor, Ogbumuo Prisca Ndidi, Ezeonyejiaku Demian Chigozie, Mogbo Tochukwu Chinedu, Ebenebe Cordelia Ifeyinwa, Aziagba, Bibian Okwuchukwu. Evaluation of Insecticidal Efficacy of Piper Guineense on Fish Beetle (Dermestes maculatus). American Journal of BioScience. Vol. 3, No. 2, 2015, pp. 41-45. doi: 10.11648/j.ajbio.20150302.13

\begin{abstract}
This research was conducted to evaluate the insecticidal efficacy of powder of plant materials Piper guineense against fish beetles, Dermestes maculatus. Eight treatments were used in dosages of; $0.02 \mathrm{~g}, 0.04 \mathrm{~g}, 0.06 \mathrm{~g}, 0.08 \mathrm{~g}, 0.05 \mathrm{~g}, 1.0 \mathrm{~g}$, $1.5 \mathrm{~g}$ and $2.0 \mathrm{~g}$ in the research and larval and adult mortalities were monitored in two separate experiments after 24 hours, 48 hours and 72 hours. Piper guineense powder at $2.0 \mathrm{~g}$ gave mortalities of $83.33 \%$ and $76.67 \%$ for larva and adult respectively. The percentage of emergence of larva and adult were $15 \%$ and $10.7 \%$ respectively when the smoked catfish (Clarias gariepinus) was treated with P. guineense powder. Also the percentage of fish loss in Piper guineense powder at $2.0 \mathrm{~g}$ was $0.88 \%$ in adult and larva $1.48 \%$. This research has revealed that the locally available botanicals insecticides could offer effective protection against post-harvest insect pest of fish and therefore could be incorporated into post-harvest fish management strategies.
\end{abstract}

Keywords: Piper Guineense, Dermestes Maculates, Clarias Gariepinus

\section{Introduction}

Fish supplies a good balance of protein, vitamins and minerals. It's relative calories content is $10 \%$ hence its nutritional value is recognized (Akande and Taobor, 1992). Fish and fish products constitute more than $60 \%$ of the total protein intake in adults especially in rural areas (Adeleye, 1992), therefore there is need for their production.Fish is a major source of protein and its harvesting, handling, processing and distribution provide livelihood for millions of people as well as providing foreign exchange earning to many countries (Al-jufaili and Opara, 2006).

Fish protein is known to be the best and cheapest sources of animal protein (Olayide, 1973). It provides about $20 \%$ protein and essential amino acids such as lysine and methionine, and it compares favorably with the protein content of egg, milk and meat. It has been estimated that post-harvest losses of fish account for between 10\% and 35\% by weight of the world fish catch as a result of poor handling, processing and storage. Losses in small-scale fisheries are even higher and can sometimes amount to $40-50 \%$ nation's catch (Lale, 2002). Dried fish is susceptible to attack by insects especially beetle species of the genera, Dermestes and
Necrobia. The loss of dried fish to its best known pest, Dermestes maculatus has been variously quantified. Under traditional storage conditions, losses due to beetle infestation for instance, have been estimated at around 50\% (Lale, 2002). Talabu (1983) reported that in the Lake Chad area of Nigeria, a lot of fish were sun dried in the open and may be dipped in $8 \%$ formulation of gammalin 20 solution before being sundried. This, it is believed will prevent insect infestation. The direct application of synthetic insecticides in this way is considered potentially dangerous. In Ghana, Bull (1982) reported that insecticides applied this way caused blurred vision, dizziness and vomiting in villages where such are consumed.

However, as alternatives to these synthetic chemicals a lot has been done by researchers in the use of botanical insecticides. Dales (1996) reported a lot of research being undertaken in many countries which include Nigeria, Ghana, Kenya, Egypt, Pakistan, the Phillipines and Japan. Teotia and Terwari (1977) noted that insecticides of plant origin, because of their high degree of tolerance by mammals, were particularly valued for application against insect pest of 
fodder, fruits, vegetable and stored produce.

Most of the botanical insecticides that have been tested include guava (Rehin and Espig, 1991), Eucalyptus (Dakshinamurthy, 1988).

Lale (2002) reported that sprinkling of fish with chili pepper (Capsicum frutescens) powders and lime juice while it is drying prevents infestation by insect pests. According to him, pulverized dried citrus peels, leaves of Boscia senegalensis and neem seed powder added to dried fish also prevents beetle infestation. In addition, some powders made from fruits, seeds, flowers, leaves, shoots, bark and roots of local medicinal/insecticidal plants have been demonstrated to be effective in protecting stored produce against pest depredation. Examples include powders from Piper guineense schum and Thonn seeds (Ivbijaro and Abaje, 1986), Zingiber officinale (Odeyemi et al.,2000), dry fruits of Capsicum species (Lale, 1992).

Toxicity to adults of Dermestes maculatus, reduction of oviposition, ovicidal activity and toxicity to immature stages prior or immediately following penetration of plant tissue have been suggested as mechanism of action of insecticidal plant powders (Lale, 1995).Egwunyenga et al., (1998) reported the repellency of powders of Dennettia tripetala to Dermestes maculatus. Also, Fasakin and Aberejo (2002) showed that pulverized plant materials affected the developmental stages of fish beetle, Dermestes maculates. Onu and Baba (2003) reported that neem kernel powder at the rate of $5 \mathrm{~g}$ per $35 \mathrm{~g}$ of fish significantly suppressed oviposition and adult emergence of D. maculatus. However, against this background, the aim of this research is to evaluate the insecticidal efficacy of Piper guineense to $D$. maculatus on dried fish during storage.

\section{Materials and Methods}

\subsection{Procurement of Experimental Animal}

Adults of four months oldand larvae of $D$. maculatus were cultured in the laboratory at laboratory temperature of $25^{\circ} \mathrm{C}$. These adult fish beetles were collected and maintained on a large quantity of fish in a plastic bucket covered with nylon mesh held in place with rubber band, using the Halstead (1963) and Stanley and Wilber (1996) methods. Freshly emerged adults of week old and late instars of $D$. maculatus larva were then used for the experiment as pure breed.

\subsection{Fish Processing}

The fish species used for this study was Clarias gariepinus. The fish were killed and cut into small sizes. They were subsequently dried using local oven and stored in an air tight container before being used.

\subsection{Plant Material Collection and Processing}

Plant material used in this study was Piper guineense, commonly known as black pepper and Uziza in Igbo language. The seeds of this plant were used for this research. The plant material collected wasair-dried in a well ventilated area for one week before they were pulverized into fine powder and sieved with a $2 \mathrm{~mm}$ mesh size.

\subsection{Procedure}

Twenty grams $(20 \mathrm{~g})$ of non-infested fish were weighed into eight $60 \mathrm{ml}$ plastic vials, to each vial, dosage of plant materials was added in the range of $0.02 \mathrm{~g}, 0.04 \mathrm{~g}, 0.06 \mathrm{~g}$, $0.08 \mathrm{~g}, 0.5 \mathrm{~g}, 1.0 \mathrm{~g}, 1.5 \mathrm{~g}, 2.0 \mathrm{~g}$ respectively, that is eight treatments in a whole. The dosage was for larvae and freshly emerged adults of the fish beetle in different experimental vials. The experiment was conducted in two ways; fifteen pairs of larva were introduced to each vial for the experiment one and fifteen pairs of adult were introduced to each vial for the experiment two. The lid of the plastic vials were perforated and secured with a netting material, this is to ensure aeration and avoid entry or exit of insects. The content of the vials were then thoroughly mixed. Each treatment was replicated three times. The number of dead larvae andadults of fish beetle was counted after 24 hours, 48 hours, and 72 hours to determine the mortality rate of larvae and adults of D. maculatus, larval and adult emergence was also assessed in the experiment. Insects subsequently emerging were counted to estimate FI progeny production. Counting was stopped after 10 days to avoid overlapping of generation.

The results were subjected to analysis of variance, the specific differences in treatment means were determined using Least Significant Difference (LSD), (Steel and Torrie, 1990).

\section{Result}

The percentage mortality of the adults and larvae of fish beetle treated with plant powder of $P$. guineense is shown in Figure 1. The result shows that treatment eight $(0.02 \mathrm{~g})$ caused $36.67 \%$ and $43.33 \%$ mortalities on adult and larva of the fish beetle respectively. However, treatment eight $(0.02 \mathrm{~g})$ caused mortalities of $76.67 \%$ and $83.33 \%$ respectively on the adults and larvae. This shows that treatment eight $(2.00 \mathrm{~g})$ dose was very effective than other doses.

The emergence of adults and larvae of D. maculatus was strongly influenced by the plant material; Piper guineense as shown in figure 2 . There was significant differences $(p<0.05)$ in the mean emergence of adult and larva of $D$. maculates. Looking at the figure 2 , in treatment eight $(0.02 \mathrm{~g})$, the adults recorded the lowest number of emergence having $37.7 \%$ while to a higher extent larvae recorded $62.7 \%$. Also in treatment eight $(2.00 \mathrm{~g})$ the adults recorded $10.7 \%$ while the larvae recorded $15 \%$ of emergence.

The result in figure 3 shows that the larval stage of this beetle is more susceptible to the treatment than the adult stage. The percentage weight loss on fish infested with adults of fish beetle $0.88 \pm 0.1$ and larva $1.48 \pm 0.6$ shows a clear influence of the plant material on the extent of damage caused by these insects during storage. However, the percentage mortality caused by the powder was more on the larval stage than the adult stage (Figure 1).This suggests that the larval stage of this beetle is more susceptible to the 
treatment than the adult stage.

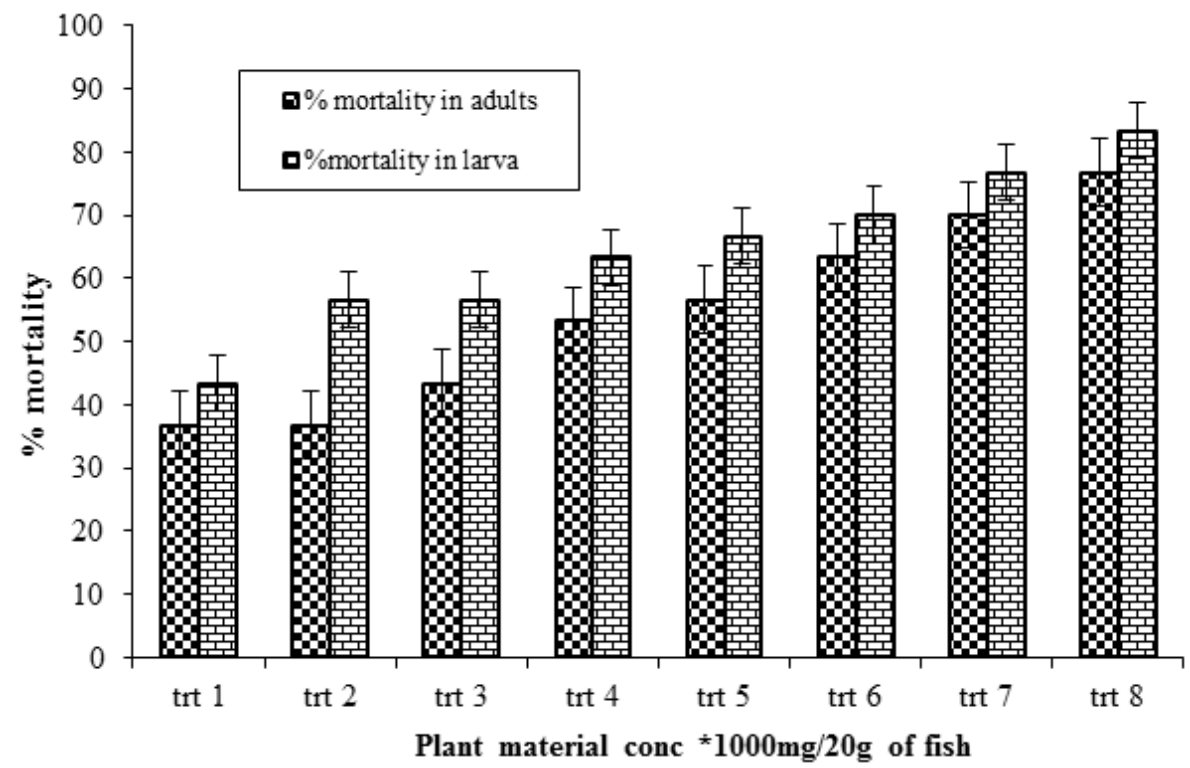

Figure 1. Percentage mortality of adults of fish beetle and larvae in different treatments.

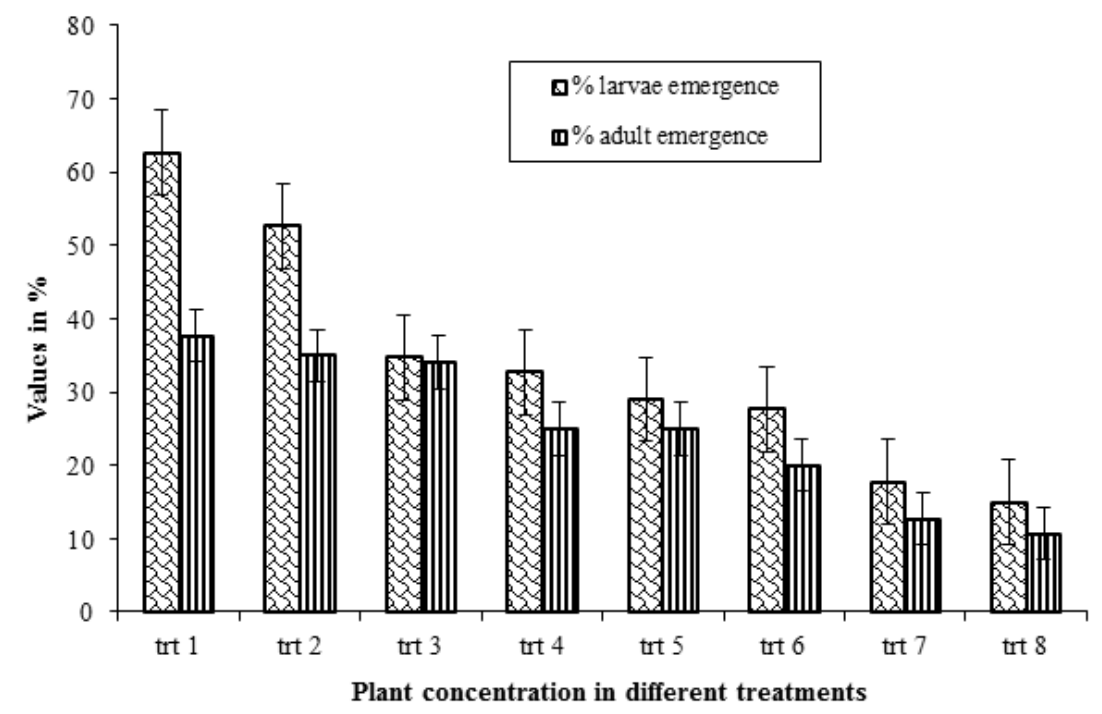

Figure $2 . \%$ of adults and larvae emergence.

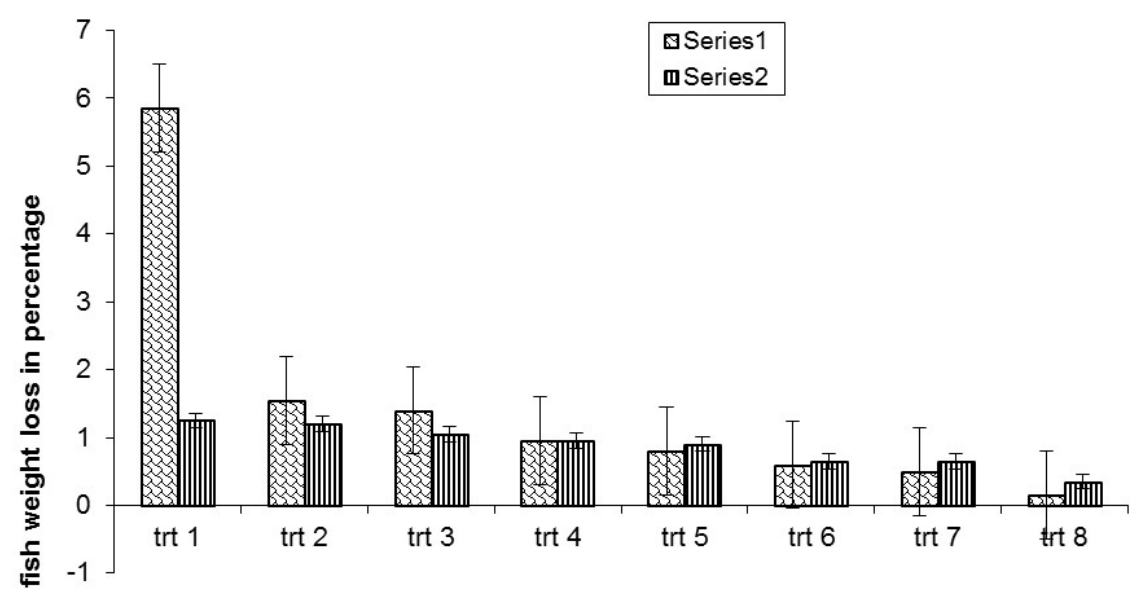

Plant concentration in different treatments

Figure 3. \% fish weight loss by larvae and adults. 


\section{Discussion}

This research was conducted to evaluate the insecticidal efficacy of $P$. guineense powder against the adult stage and larval stage of fish beetle, D. maculatus on smoked catfish, Clarias gariepinus. The resultant high mortality of larval and adult stages of the beetle observed on dried fish treated with the plant material could be due to high toxic effect of this products on both larval and adult stages of $D$. maculates.

Insecticidal property of any plant material would depend on the active constituents of the plant material. It was reported that $P$. guineense contains piperine and chavicine, which are insecticidal including piperidine and alkaloids as the major active components in P. guineense seeds (Lale, 1995).

However, the toxicity has been attributed by various authors to their pungent and pepperish taste which could asphyxiate insects by blocking the spiracles and the presence of bioactive ingredients such as alpha-pinene, limonene and Linalool in $P$. guineense (Golob et al., 1999).Similar observation have also been made by Adedire and Lajide, (1998) that plant materials within the family Piperaceae to which Piper guineense belongs have been reported to possess some form of insecticidal properties against eggs of cowpea storage, Bruchid, and also capable of suppressing various developmental instars of Callosobruchus maculatus.Odeyemi et al., (2000) also observed that cases of high mortality reported in the larvae was partly because of their inability to detoxify plant toxins during feeding activity, especially at $1^{\text {st }}-4^{\text {th }}$ larval stage. According to the authors larvae are voracious eaters because of their growth requirement in contrast to adult stage of the insect, which tend to have a reduced feeding habit. In the present study, high larval mortality was observed in $P$. guineense treated fish.

The observed low emergence of F1 generation of $D$. maculatus on dried fish treated with $P$. guineense could be due to high mortality of the late instar larvae resulting from toxic effects of the plant products. Similar observations have been reported by some authors on the disruptive effect of $P$. guineense. Fasakin and Aberejo, (2002) reported that pulverized plant materials from $P$. guineense inhibited egg hatchability and adult emergence of D. maculatus Degeer in smoked catfish (Clarias gariepinus) during storage.

\section{Conclusion}

From the results obtained from this research, it shows that $P$. guineense has the insecticidal potentials as plant against fish beetle, D. maculatus in Nigeria. The protective and toxic effect of the powder in addition to its local availability makes it attractive material in up grading traditional post-harvest protection practices. The effectiveness of $P$. guineense in reducing damage and controlling $D$. maculatus infestation in smoked fish during storage could be encouraging and a possible means of ensuring a steady supply of good quality dried fish. $P$. guineense is worth to be used as a naturalinsecticide of dried fish and other stored products against their insect pest and therefore can serve as an affordable substitute for synthetic insecticide.

\section{References}

[1] Adedire, C. O. and Lajide, L., (1999). Toxicity and Oviposition Deterrency of some plants extracts on cowpea storage Bruchid, Callosobruchus maculatus Fabricius. Journal of Plant Diseases and Protection 106:647-653.

[2] Adeleye, O.A., (1992). Conservation Needs of Fisheries Resources and Reorientation for Sustainable Capture and CulturePractices. Proceedings of the $10^{\text {th }}$ annual Conference Fisheries Societies of Nigeria, pp. 230-234.

[3] Akande,G. R. andTaobor, J G., (1992). Improved Utilization and Increased Availability of fishing product as an effective Control Aggravated Animal Protein Deficiency Induced Malnutrition in Nigeria. Proceedings of the 10th annual conference of the fisheries society of Nigeria.Pp.18-31.

[4] Al-Jufaili, M. S. and Opara, L. U., (2006). Status of fisheries post harvest industry in the sultanate of Oman: part 1 handling and marketing system of fresh fish. Journal of fisheries International, 1 (2-4): 144-149.b.

[5] Bull, D., (1982). Pesticide and Third World Poor. Oxford Public Affair Unity. Pp. 54-62.

[6] Dakshinamurthy A., (1988). Effects of Certain Plant Products on Storage Pest of Paddy. Tropical Science, 28:119-122.

[7] Dales, M. J., (1996). A review of plant materials used for controlling Insect pest of Stored Product. Natural Resources Institute. Bullentin, Chanthan, UKpp. 65

[8] Egwunyenga, O. A., Alo, E. R. and Nmoisi, O. P. G., (1998). Laboratory Evaluation of the Repellency of Dennettia tripetala Baker (Anonaceae) to Dermestes maculatus (F.) (Coleoptera:Dermestidae) .Journal of Stored Products Research, 34 (2-3):195-199.

[9] Fasakin, E. A. and Aberejo, B. A., (2002). Effect of some pulverized plant materials on the Developmental stages of fish beetle. Dermestes maculatus Degeer in smoked catfish (Clarias gariepinus)during storage. Bioresource Technology, 87:173-177.

[10] Golob,O.J ., Mwumbola, V., Mbhango and Ngulube, F.,(1999). The use of locally available materials as Protectants of Maize grains against Insects Infestation during storage in Malawi. Journal of stored products resource, 18:67-74.

[11] Halstead, D .G. H., (1963). Eternal sex difference in stored products. Coleopteran. Bulletin of EntomologicalResearch 54:119-134.

[12] Ivbijaro, M. F. and Abaje, M., (1986). Insecticidal Activities of Piper guineense and Capsicum species on the Cowpea Bruchid Callosobruchus maculatus. Insect Science and its application 7:521-524.

[13] Lale, N.E.S., (1992). Oviposition deterrent and repellent effects of products, Chilli pepper fruits,Capsicum species on Callosobruchus maculatus. Post-Harvest Biology and Technology, 1: 343-348. 
[14] Lale, N .E. S., (1995). An Overview of the use of Plant Products in the Management of stored Product-Coleoptera in the tropics. Post Harvest News Information 6:69-75.

[15] Lale, N. E. S. and Alaga, K. A., (2002). Exploring the Insecticidal, Larvicidal and Repellant properties of Piper guineense Schum and Thonn seed oil for the control of rust red flour beetle Tribolium castaneum (Herest) in stored Pearl millet, Pennistum glaucum (L) .Journal of Biological Sciences 7(7):1215-1220.

[16] Odeyemi, O. O., Owoade,R . A. and Akinkurolere, R., (2000). Toxicity and population Suppression effects of Paskia clappertonia on dried fish Pest (Dermestes maculates). Global Journal of Pure and Applied Science, 6;191-195.

[17] Olayide, S .O., (1973). A quantitative study of food equipment, supply and demand in Nigeria. UI press, Nigeria, 133pp.

[18] Onu, I. and Baba G O., (2003). Evaluation of Neem products (Azadiracha indica A. juss Meliaceae ) for the control of Dermestid beetle (D. Maculatus Degeer) (Coleptera: Dermestidae) on dried fish. Nigerian Journal of Entomology, 20:105-115.
[19] Rehin, S. and Espig, G., (1991). The cultivated plants of the dried fish trade in Nigeria with particular reference to Lake Chad. Tropical stored product information, 5:162-167.

[20] Stanley, P. G. and Wilber, D. A., (1996). Colour characteristics of sexing life adults of lesser grain borer. Journal of Economic Entomology, 59:760-761.

[21] Steel, R. G. D. and Torrie, J. H. (1990). Princiles and procedures of statistics. McGraw-Hill, New York, 451pp.

[22] Talabu, S. O., (1983). Fish drying and smoking in NIOMRA technological breakthrough in fish preservation. Nigerian institute of oceanography and marine research (NIMORA) Seminar Series No2, pp 10.

[23] Teotia T. P. S., Tewari, G. C., (1997). Insecticidal properties of drupes of Dharek, (Melia azedrachta) and rhizomes of sweet flag (Acorus calamus) against adults of Sitatroga cerelia (Oliver). Indian Journal of Entomology 39(39):222-227. 